\title{
EVICTION OF A TENANT AFTER TERMINATION OF A LEASE OF RESIDENTIAL PREMISES
}

\section{$1 \quad$ Introduction}

This Note examines the procedure to be followed to evict a tenant of residential premises where the lease has terminated but the tenant refuses to vacate. Attention is given firstly to the position at common law. The provisions of the Prevention of Illegal Eviction from and Unlawful Occupation of Land Act 19 of 1998 ("the PIE Act") are discussed next, together with the judgment in Ndlovu v Ngcobo; Bekker $v$ Jika (2003 1 SA 113 (SCA)) which held that the eviction of a tenant (being a natural person) from a dwelling is no longer governed by common law but by the provisions of the PIE Act. The focus then falls on the Prevention of Illegal Eviction from and Unlawful Occupation of Land Amendment Bill 2008 which, amongst others, seeks to undo the Ndlovu judgment, subject to certain exceptions. It is argued that the Bill fails to distinguish between the various categories of landlords in the residential letting market, and as a result fails to recognize that certain tenants rightfully qualify for protection under the PIE Act.

The note concludes by analyzing the position should the PIE Amendment Bill become law. It is submitted that although the PIE Act would as a general rule no longer govern the eviction of tenants from dwellings, the provisions of section 26(3) of the Constitution will still apply. This provides that "no one may be evicted from their home ... without an order of Court made after considering all the relevant circumstances". The application of the section is examined in the context of eviction proceedings instituted by landlords of residential premises.

\section{Common law}

At common law one of the incidents of ownership of a property is the owner's right of exclusive possession of the property, with the necessary corollary that the owner may claim the property from whomever is holding it: Chetty $v$ Naidoo (1974 3 SA 13 (A)). Accordingly, where a landlord's claim for eviction is based on his ownership of the property his cause of action is simply the fact of his ownership coupled with the fact that possession is held by the defendant (tenant): Akbar v Patel (1974 4 SA 104 (T)). In stating his claim the landlord need not allege that the tenant's possession is unlawful or against the landlord's will, or that there was a lease which had been terminated - the onus being on the tenant to allege and establish any right to hold the property against the owner: Chetty $v$ Naidoo (supra 20A). In practice, however, an owner-landlord suing for ejectment would often include an allegation in his 
particulars of claim that he has granted the defendant a lease but that this has been terminated. Although this is strictly speaking an unnecessary allegation where eviction is sought based on ownership, it is a convenient way of anticipating the defendant's plea that he is in possession by virtue of a lease, which will call for a replication that the lease has been terminated: Graham v Ridley (1931 TPD 476). Either way the onus is on the landlord to prove that the lease had been validly terminated: Chetty $v$ Naidoo (supra 21H-22F); Schnehage v Bezuidenhout (1977 1 SA $362(0)$ ).

An owner-landlord is not obliged to base a claim for eviction on his rights of ownership. He may simply rely on his common law right as landlord that the tenant has to vacate the premises after termination of the lease and restore the property to the lessor: Kerr (The Law of Lease 2ed (1976) 134). In this regard the fundamental allegations to be made are that the plaintiff, as landlord, had concluded a lease with the defendant as lessee; that the lease had been validly terminated on the grounds stated in the particulars of claim (eg, effluxion of time, breach of contract on the part of the lessee or whatever the case may be) and that the defendant has refused to vacate the premises and restore same to the landlord, despite the termination. Obviously a landlord who is not the owner has no choice but to base an eviction claim on these grounds.

A tenant facing an eviction claim at common law has no defence based on equity considerations. Unless the tenant can establish some legal right to remain in occupation despite termination of the lease (eg, a right of retention in respect of necessary or useful improvements effected during the currency of the lease - Business Aviation Corporation (Pty) Ltd $v$ Rand Airport Holdings (Pty) Ltd 20066 SA 605 (SCA)), an eviction order must be granted. Accordingly, a Court has no discretion to refuse the order on the grounds that the tenant may suffer hardship following the eviction or that he will be rendered homeless. This applies whether the landlord is an organ of State, a large public company or a private individual. The fact that the premises will be left unoccupied for a lengthy period after the eviction is equally irrelevant.

The eviction of a tenant after termination of the lease is therefore a relatively straightforward exercise at common law. The landlord must, however, follow legal process: he cannot resort to self-help, not even if a clause in the lease agreement purportedly empowers him to do so. Any such clause is against public policy and therefore unenforceable: Blomson $v$ Boshoff (1905 TS 429); Nino Bonino v De Lange (1906 TS 120); and Smith v Rand Bank Bpk (1979 4 SA $228(\mathrm{~N})$ ).

\section{Prevention of Illegal Eviction from and Unlawful Occupation of Land Act 19 of 1998}

The PIE Act has its roots in section 26 of the Constitution, more specifically section 26(1), which confers on every person the right to have access to adequate housing, and section 26(3) whereby "no one may be evicted from their home, or have their home demolished, without an order of court made 
after considering all the relevant circumstances. No legislation may permit arbitrary evictions." The Act applies in respect of all land throughout South Africa (s 2) and prohibits the eviction of an "unlawful occupier" except on the authority of an order of a competent court (s 8(1)). "Evict" is defined to mean "to deprive a person of occupation of a building or structure, or the land on which such building or structure is erected, against his or her will". "Building or structure" by definition includes "any hut, shack, tent or similar structure or any other form of temporary or permanent dwelling or shelter". An "unlawful occupier" is defined as

\begin{abstract}
"a person who occupies land without the express or tacit consent of the owner or person in charge, or without any other right in law to occupy such land, excluding a person who is an occupier in terms of the Extension of Security of Tenure Act, 1997, and excluding a person whose informal right to land, but for the provisions of this Act, would be protected by the provisions of the Interim Protection of Informal Land Rights Act, 1996 (Act No. 31 of 1996)".
\end{abstract}

A "person in charge" refers to "a person who has or at the relevant time had legal authority to give permission to a person to enter or reside upon the land in question". It therefore includes a landlord who is not the owner of the premises but has the owner's express or implied authority to enter into a lease.

Section 4 regulates the eviction of unlawful occupiers by an owner or person in charge of land, while section 6 specifically provides for evictions at the instance of organs of State. An organ of State owning the land that is unlawfully occupied may proceed for eviction in terms of either section 4 or section 6 (City of Cape Town v Unlawful Occupiers, Erf 1800, Capricorn (Vrygrond Development) 20036 SA 140 (C)), but an organ of State seeking the eviction of unlawful occupiers from land not owned by such organ of State must follow the procedure set out in section 6: Mangaung Local Municipality $v$ Mashale (2006 1 SA $269(0)$ ). For present purposes it is necessary only to focus on the provisions of section 4 . The position is as follows:

- At least 14 days before the hearing of the eviction proceedings contemplated by the owner or person in charge the Court must serve written and effective notice of the proceedings on the unlawful occupier and the municipality having jurisdiction: section 2 . The notice must be served in the manner prescribed by the rules of the court in question (s 3 ) but if this cannot be done conveniently or expeditiously, service must be effected in the manner directed by the court: section 4 . The notice must contain the particulars set out in section 5 , namely it must

(a) state that proceedings are being instituted in terms of section 4(1) of the PIE Act for an order for the eviction of the unlawful occupier;

(b) indicate on what date and at what time the court will hear the proceedings;

(c) set out the grounds for the proposed eviction; and

(d) state that the unlawful occupier is entitled to appear before the court and defend the case and, where necessary, has the right to apply for legal aid. 
- The grounds upon which an eviction order can be made are set out in sections 6 and 7. A distinction is drawn between an eviction where the unlawful occupier has occupied the land in question for less than six months at the time when the proceedings are initiated, and where he or she has done so for more than six months. In the first scenario (s 6) a court may grant an order for eviction if it is of the opinion that it is just and equitable to do so, after considering all the relevant circumstances, including the rights and needs of the elderly, children, disabled persons and households headed by women. The grounds for eviction in the second scenario are the same, except that the Court is also required to consider whether land has been made available or can reasonably be made available by a municipality or other organ of state or another landowner for the relocation of the unlawful occupier. This additional factor need not be considered by the Court where the land is sold in a sale of execution pursuant to a mortgage.

- If the court is satisfied that all the requirements of section 4 have been complied with and that no valid defence has been raised by the unlawful occupier, it must grant an order for the eviction of the unlawful occupier: section 8 . It must also then determine a just and equitable date on which the unlawful occupier must vacate the land under the circumstances, and the date on which an eviction order may be carried out if the unlawful occupier has not vacated the land on the said date. In determining a just and equitable date on which the unlawful occupier must vacate the land the court must have regard to all relevant factors, including the period the unlawful occupier and his or her family have resided on the land in question: section 9 .

It has been said that the PIE Act is essentially socialistic in nature; that it is a piece of welfare legislation formulated upon humanitarian lines, and that the procedures to be followed in terms of the Act before an eviction order can be issued have made inroads into the rights of property owners to pro-tect their property against unlawful occupation: Port Elizabeth Municipality $v$ Peoples Dialogue on Land Shelter (2000 2 SA 1074 (E)). The Act must, however, be viewed in a constitutional context. As was pointed out by the Constitutional Court (Port Elizabeth Municipality v Various Occupiers 20051 SA 217 (CC)) the starting and ending point of any analysis of the Act must necessarily be "to affirm the (constitutional) values of human dignity, equality and freedom". Moreover, the Constitution imposes new obligations on the courts concerning rights relating to property, not previously recognised by the common law. In contra-distinction to the normal ownership rights of possession, use and occupation there is now a new and equally relevant right not arbitrarily to be deprived of a home. In the circumstances the expectations that ordinarily go with ownership could therefore clash head-on with the genuine despair of people in dire need of accommodation (Port Elizabeth Municipality $v$ Various Occupiers supra). It would thus be correct to state that although the Act does not abolish an owner's common law right to the exclusive enjoyment of his property and the owner's inherent right to the legal protection of his property (Port Elizabeth Municipality v Peoples Dialogue on Land Shelter supra) it is 
clear that "the Legislature, somewhat imperceptibly and indirectly, disposed of common law rights in promoting social rights": Ndlovu v Ngcobo; Bekker v Jika (supra). This is part and parcel of a more liberal and enlightened land reform policy in South Africa (Port Elizabeth Municipality v Peoples Dialogue on Land Shelter supra) and a more "nuanced application" of a property owner's proprietary rights post the Constitution: Stock v Minister of Housing (2007 2 SA 9 (C)).

\section{Ndlovu v Ngcobo; Bekker v Jika}

Landlords initially took little notice of the PIE Act, believing that it does not apply to the eviction of tenants whose leases had been lawfully terminated. They were supported by two judgments, namely Absa Bank Ltd $v$ Amod ([1999] 2 All SA $423(\mathrm{~W})$ ) and Ellis $v$ Viljoen (2001 4 SA $186(C))$. In the first Schwartzman $\mathrm{J}$ specifically remarked that it was difficult to accept that an affluent tenant who rents a luxury home for a limited period should enjoy the protection afforded by the PIE Act, while in the latter it was expressly held that the Act does not apply to a situation where property is occupied by a person who initially took occupation thereof in terms of a contract or with the consent of the owner, but whose right to remain in occupation has since been terminated. Landlords of residential premises were furthermore comforted by section 4(5)(d)(ii) of the Rental Housing Act 50 of 1999 which states expressly that a landlord has the (unqualified) right on termination of a lease to "repossess the rental housing property having first obtained an order of court". There are no indications in the latter Act that the legislature had any intention of interfering with a landlord's rights at common law to obtain an eviction order after termination of the lease, or of disallowing the landlord from repossessing the property after termination of the lease on the grounds that it would be just and equitable to do so, thereby allowing the tenant to remain in occupation.

The judgment in Ndlovu v Ngcobo; Bekker $v$ Jika (supra) took landlords by surprise. Two appeals served before the Supreme Court of Appeal. In Ndlovu a tenant's lease had been terminated lawfully but he refused to vacate. In Bekker a mortgage bond had been called up; the property was sold in execution and transferred to the buyer, but the former owner refused to leave. In both cases eviction orders were sought but the procedural requirements of the PIE Act had not been met. The sole question for decision by the SCA was whether compliance with the requirements was obligatory. Having regard to the definition of "unlawful occupier" in the Act the majority of the Court found that textually the Act applies to all unlawful occupiers, irrespective of whether their possession was at an earlier stage lawful. Speaking for the majority, Harms JA then proceeded to consider whether there were any "external factors" that could indicate that the legislature did not intend to cast the net so wide. He found none. The learned judge of appeal referred to the affluent tenant example postulated by Schwartzman $\mathrm{J}$ in Absa Bank Ltd v Amod (supra) but then also considered other examples raised by counsel, such as where a tenant of a shack in a township loses his work or falls ill and cannot afford to pay the rent, or the tenant in a township 
whose tenancy is terminated by virtue of some township regulation and has nowhere else to go. Counsel posed the question why these persons should be in a worse position than those whose initial occupancy was illegal. In this regard Harms JA remarked as follows (par 16):

"There is clearly a substantial class of persons whose vulnerability may well have been a concern of Parliament, especially if the intention was to invert PISA. It would appear that Schwartzman $\mathrm{J}$ overlooked the poor, who will always be with us, and that he failed to remind himself of the fact that the Constitution enjoins courts, when interpreting any legislation, to promote the spirit, purport and objects of the Bill of Rights, in this case s 26(3). The Bill of Rights and social or remedial legislation often confer benefits on persons for whom they are not primarily intended. The law of unintended consequences sometimes takes it toll. There seems to be no reason in the general social and historical context of this country why the Legislature would not have wished not to afford this vulnerable group the protection of PIE. Some may deem it unfortunate that the Legislature, somewhat imperceptibly and indirectly, disposed of common law rights in promoting social rights. Others will point out that social rights do tend to impinge or impact upon common law rights, sometimes dramatically."

The judge of appeal then proceeded to explain that the landlord's problem with the affluent tenant was in any event not as oppressive as it seemed at first. While conceding (par 17) that the tenant would obviously be entitled to the "somewhat cumbersome procedural advantages of PIE to the annoyance of the landlord" Harms JA explained that section 4(6) would apply if the landlord proceeded to apply for eviction with "due haste"; if he was "a bit slower" section 4 (7) would come into play, which required of the Court to consider whether land has been made available or can reasonably be made available by a municipality or other organ of State or another land owner for the relocation of the unlawful occupier. According to the learned judge of appeal this added consideration would not be apposite since the imagined affluent person would not wish to be relocated to vacant land possessed by a local authority. According to Harms JA the rights and needs of the elderly, children disabled persons and households headed by women will not arise in such a case (elsewhere - par 10 - the judge remarked that those rights need not be considered under $s \quad 4(7)$ ) and he then asked what relevant circumstances would there otherwise be save that the applicant/landlord is the owner, that the lease has come to an end and that the tenant is holding over.

According to Harms JA another material consideration was that of the evidential onus. In this regard the learned judge of appeal held that if the procedural requirements have been met, the owner is entitled to approach the court on the basis of ownership and the respondent's unlawful occupation. Unless the occupier opposes and discloses circumstances relevant to the eviction order, the owner, in principle will be entitled to an order for eviction. It cannot be expected of an owner to negative in advance facts not known to him and not in issue between the parties.

Counsel for the landlord argued that PIE must be seen in the context of its "legislative context". He listed three statutes, namely the Extension of 
Security of Tenure Act 3 of 1997, the Rental Housing Act 50 of 1999 and the Land Reform (Labour Tenants) Act 3 of 1996. These Acts, so it was contended, formed a mosaic, each aimed at protecting a different class of occupier. Accordingly, the rights of tenants holding over are to be found exclusively within the parameters of the Rental Housing Act and not in PIE. Harms JA was not persuaded (par 22):

\begin{abstract}
"The answers to the submission are manifold. The submission skirts around the issue of interpretation of PIE and does not confront it directly. It assumes that these pieces of legislation form, by design or chance, a mosaic and it discounts the possibility that they are but pieces of an incomplete jigsaw puzzle. It relies on a later Act (the Rental Housing Act) to interpret an earlier enactment (PIE). It assumes that Parliament does not pass overlapping Acts. If one examines these laws even cursorily it is obvious that they were not intended to form a mosaic in the sense suggested by counsel: they deal with related matters in often completely different ways and there are at the same time overlapping and uncovered areas. It follows that this argument must also fail."
\end{abstract}

The SCA thus concluded that the PIE Act does indeed apply to tenants who unlawfully remain in occupation of the leased premises after termination of the lease. It observed, however, that the Act does not apply to buildings or structures that do not perform the function of a form of dwelling or shelter for humans, and since juristic persons do not have dwellings their unlawful possession is similarly not protected by the PIE Act (par 20).

The SCA's judgment did not find favour with the property industry. The SA Property Owners Association (SAPOA) expressed its concern that the application of the PIE Act to bond and rent defaulters would put severe strain on the property market and would discourage foreign investment ("More Anger at Eviction Ruling" http://www.fin24.com/articles/default/display_article. aspx?Nav=ns\&ArticlelD=1518-25_1254736). The Banking Council expressed similar concerns. The Estate Agency Affairs Board pointed out that those hardest hit will be prospective tenants with low incomes and low credit ratings; for them, finding rental accommodation could become extremely difficult following the SCA's ruling: see www.eaab.org.za/attachment _view.php?pa_id=85. Letting agents contended that in theory having to obtain a court order to evict a tenant was not unreasonable, but the reality was that the sluggish legal process and the overburdened courts meant that an order to evict could take up to four months to be granted: see "Ruling in Favour of Those Who Default May Backfire" (2004-06-21 Business Day).

Some of these concerns may well have been exaggerated, but there can be no denial that the application of the PIE Act to each and every lease of a dwelling does pose some difficulties. Consider the following:

(a) In terms of section (1) the provisions of section 4 apply to proceedings by an owner or person in charge of land for the eviction of an unlawful occupier notwithstanding anything to the contrary contained in any law or the common law. This makes it abundantly clear that an owner seeking the eviction of an unlawful occupier can no longer rely on the common law as outlined above, but is compelled to follow the procedure set out in section 4: City of Cape Town v Rudolph (2004 5 SA 39 (C)). This is so 
even if the tenant clearly has no bona fide defence whatsoever: the procedural requirements of the Act have to be followed. The inevitable consequences are that costs are increased and the eviction process is lengthened. It also places further strain on the already heavily burdened courts. In an application for eviction in the High Court a notice of motion as prescribed by the Rules of Court must be served first and the notice contemplated in section 4(2) of the PIE Act at a later stage: Cape Killarney Property Investments (Pty) Ltd v Mahamba (2001 4 SA 1222 (SCA)). The notice contemplated in section 4(2) can only be authorised and directed by the Court after all the papers on both sides have been served. Potential evictees must therefore receive two notices prior to the Court considering whether or not to grant an eviction order. Two services are required (that of the application papers and that of the $s 4(2)$ notice) as well as two appearances, the first being for the authorisation of the section 4(2) notice and the second being to obtain the relief for eviction: Kanescho Realtors (Pty) Ltd $v$ Maphumulo and Three Similar Cases (2006 5 SA 92 (D)).

(b) Procedural errors may have the effect that the entire eviction process is defective. For example, there is no substantial compliance with the Act if a section 4(2) notice was authorised but the date for hearing not inserted therein and the respondent is notified that a notice of set-down would be served upon him in due course: Kanescho Realtors (Pty) Ltd $v$ Maphumulo and Three Similar Cases (supra).

(c) Although a Court will not allow a tenant whose lease has been lawfully terminated to continue in occupation of the premises in a parasitic fashion under the guise of protection afforded by the PIE Act, fact remains that the Act may be abused by former tenants in an attempt to delay or escape eviction: see the facts in FHP Management (Pty) Ltd $v$ Theron NO (2004 3 SA 392 (C)); and Davids $v$ Van Straaten (2005 4 SA 468 (C)). For example, the question whether a section 4(2) notice is effective is a question of fact, not law, which more often than not is capable of determination only after the event: Unlawful Occupiers, School Site $v$ City of Johannesburg (2005 4 SA 199 (SCA)). This opens the door for a tenant to delay the eviction process by simply attacking the validity of the notice.

(d) The Act cannot be interpreted to mean that the eviction of a tenant is automatically just and equitable if the lessor is the owner and the lease has been validly terminated. The Court must consider all relevant circumstances, including the rights and needs of the elderly, children, disabled persons and households headed by women. With respect, Harms JA misread section 4(7) of the PIE Act. The section does not exempt a Court from the duty to consider the rights and needs of the elderly, children disabled persons and households headed by women. What it says is that where the land is sold in a sale of execution pursuant to a mortgage, a Court need not consider whether land has been made available or can reasonably be made available by a municipality or other organ of State or another landowner for the relocation of the unlawful 
occupier. The rights and needs of the elderly, children, disabled persons and households headed by women must be considered in all eviction applications governed by the PIE Act. Not only must the Court consider the factors specifically mentioned in sections $4(6)$ and (7), but it must also have regard to the personal circumstances of those who will be deprived of accommodation if the eviction order is granted: Absa Bank Ltd $v$ Murray (2004 2 SA 15 (C)). What is most important, however, is the purpose of considering these factors, namely to determine whether it is just and equitable to grant the eviction order sought by the applicant. The legislature obviously contemplated that there could be instances where a consideration of the relevant circumstances would justify a finding that an eviction order would not be just equitable, despite the fact that the lease had been validly terminated. There is therefore always the possibility, remote as it may seem, that a landlord will not succeed in an eviction application despite the fact that the lease has been validly cancelled. If there is no such possibility the Act would have stated it clearly. While it is true that the affluent tenant will have grave difficulties persuading a Court to refuse an eviction order (see Wormald $v$ Kambule case no. 524/2004 (SCA) delivered 22 September 2005), not every tenant facing eviction proceedings qualify to be labeled as affluent. Also, a tenant may well have been affluent at the time of entering into the lease agreement but end up a pauper at termination of the lease following financial misfortune. Accordingly, a landlord of premises in an upmarket suburb is not necessarily guaranteed that he will succeed in obtaining an eviction order against his erstwhile affluent tenant. In short: all landlords, some more than others, face the risk that an application for eviction may not succeed by reason of the Court deciding that it would not be just and equitable to grant the order. The risk may be small, but it remains a risk that did not exist at common law.

(e) The section 4(2) notice must be served on the relevant municipality even if the eviction application in question is entirely a matter between two individuals, not remotely involving the interests of the municipality. A municipality receiving such notice cannot simply ignore it. The municipality must take it on itself to intervene and ensure that it is joined in the proceedings as one of the respondents if there is a dispute or potential dispute between the parties. In other words, in every case where there appears to be a dispute between the parties but the municipality had not been joined in the notice that had been served on it, the municipality ought to take appropriate steps to ensure that it is a party in the proceedings: Cashbuild (South Africa) (Pty) Ltd v Scott (2007 1 SA 332 $(\mathrm{T})$ ). The municipality must specifically apply its mind whether to appoint one or more persons with expertise in dispute resolution, in an endeavour to settle the dispute (Cashbuild (South Africa) (Pty) Ltd $v$ Scott supra). It may rightfully be asked whether it is at all appropriate to burden the administration of a municipality in this manner in each and every case where there is an eviction dispute between a landlord and tenant. A municipality obviously has an interest in cases where the eviction is sought of a large group of persons who invaded private land within the 
municipal boundaries, since the eviction may simply trigger a squatter problem elsewhere within the municipal area. The same may apply where the owner of a dysfunctional building in an industrial area seeks to evict a large number of persons whom he has allowed to occupy the premises for a nominal monthly "rental". But these situations are not remotely comparable with a case where a landlord is engaged in an eviction dispute with a single tenant to whom he has let a mansion in an upmarket suburb. Engaging the municipality in such a dispute is a pure waste of public resources.

These concerns cannot be simply brushed aside. Not every landlord is a slumlord, not every tenant a vulnerable victim of misguided land tenure policies of the past. In Ndlovu the Supreme Court of Appeal was faced with one of two possibilities: either the PIE Act governs the eviction of former tenants, or it does not. It was not within the Court's powers to redraft the Act so as to exclude certain categories of unlawful tenants from the operation of the Act. That is the task of the legislature, a task which it embarked upon soon after the Ndlovu judgment. Its efforts in this regard are discussed next.

The Prevention of Illegal Eviction from and Unlawful Occupation of Land Amendment Bill 2008

Somewhat surprisingly, government was quick to respond following the judgment in Ndlovu. Ministerial pronouncements made it clear that it had never been the legislature's intention that the PIE Act should protect mortgage bond and rent defaulters, and that legislation would be introduced to rectify the matter. This proved to be easier said than done - today, five years later, the Ndlovu judgment still stands. Government's first step was on 27 August 2003 when the Department of Housing published a draft Prevention of Illegal Eviction from and Unlawful Occupation of Land Amendment Bill, 2003 (GN 2276 in GG 25391). This led to the Prevention Of Illegal Eviction from and Unlawful Occupation Of Land Amendment Bill [B 11-2005], published on 14 April 2005 (the explanatory memorandum was published in GG 27370 of 18 March 2005). The latter Bill was withdrawn shortly after its publication and a statement was issued explaining that the departments of Housing and Land Affairs would discuss the matter and determine the way forward. The next development occurred on 22 December 2006 with the publication of the draft Prevention of Illegal Eviction from and Unlawful Occupation Of Land Amendment Bill, 2006 (GN 1851 in GG 29501 of 2006-12-22), which culminated in the Prevention of Illegal Eviction from and Unlawful Occupation Of Land Amendment Bill, 2008 [B 8-2008] of which the explanatory memorandum was published in GG 30458 of 2007-11-16. This is where matters stand as the date of preparation of this note (28 November 2008).

The 2008 Bill proposes a number of important amendments to the PIE Act. For present purposes only the amendments suggested in respect of section 2 of the Act need to be highlighted. In this respect the Bill proposes that the 
current section 2(2) be substituted with the following provision and that a new section 3 be added:

"(2) This Act does not apply to a person who occupied land -

(a) as a tenant;

(b) in terms of any other agreement; or

(c) as the owner of land,

and who continues to occupy the land in question despite the fact that the tenancy or agreement has been validly terminated or the person is no longer the owner of the land.

(3) Notwithstanding subsection (2), a court may order that this Act applies if the court is satisfied that any act or omission by the owner or person in charge of land was calculated to avoid the application of this Act."

The explanatory memorandum to the Bill explains the reasons underlying the amendment as follows:

"It was not the intention that the Act should apply to tenants and mortgagors who default in terms of their prior agreements with landlords and financial institutions, respectively. The Act should cover only those persons who unlawfully invade land without the prior consent of the landowner or person in charge of land. It has thus been necessary to amend section 2 of the Act (application section) to state specifically that the Act does not apply to a person who occupied land as a tenant, in terms of any other agreement or as the owner of land and who continues to occupy despite the fact that the tenancy or agreement has been validly terminated or the person is no longer the owner of the land.

A problem that may arise as a result of the amendment of section 2, is that an owner or person in charge of land may try to avoid the application of the Act, e.g. by entering into a simulated agreement with unlawful occupiers, only to terminate it shortly afterwards. In this regard the Bill seeks to grant a court the power to order that the Act applies if it is satisfied that any act or omission by the owner or person in charge of land was calculated to avoid the application of this Act."

The property industry welcomed government's stated intention to undo the Ndlovu judgment. The Estate Agency Affairs Board had the following to say about the matter (http://www.eaab.org.za/page.php?p_id=51):

"The Board, whilst fully supportive of the original intention of the PIE Act, welcomes the proposed amendment which, it believes, will restore the status quo (sic) to the rental housing market. A current shortage of rental accommodation in urban areas was, unfortunately, exacerbated by the interpretation of the Supreme Court of Appeal. Potential landlords were, as a result, extremely wary of renting out accommodation to tenants for fear that recalcitrant tenants could not be evicted at all or only evicted after the lengthy and expensive process envisaged in the PIE Act had been complied with. Even those landlords who were, perforce, prepared to rent out property sought to mitigate the possibility of loss by securing rental deposits far in excess of what otherwise would have been the case. This necessarily redounded to the prejudice of lessees. The amendment will address these very real problems."

Not all commentators shared similar views. Commenting on the 2006 Amendment Bill (which also proposed the undoing of the Ndlovu judgment) the Centre for Applied Legal Studies at the University of the Witwatersrand submitted that the Amendment Bill "will create undesirable and constitutionally unjustifiable inequalities between groups of occupiers who are equally 
in need of the PIE Act's protection. It will increase the likelihood and frequency of evictions which lead to homelessness. It may enable organs of state to evict occupiers of state-owned land without considering their needs for alternative housing." It furthermore contended (par 17-19) that:

\begin{abstract}
"Many of the rent or bond defaulters CALS has represented are people who have defaulted on their leases or bonds precisely because their socioeconomic status has declined, either because they have been retrenched from their jobs, a major income earner in the household has died (often of HIV/AIDS) or their informal livelihood strategies have been thwarted by an increasingly formalising and repressive local state, which perceives informal economic activity to be at odds with urban regeneration. CALS submits that the PIE Bill, if passed, may allow many of these peoples' housing needs to be completely ignored in court proceedings for their eviction, simply because, through no real fault of their own, they have defaulted on their lease or bond. The local municipality will not be asked to consider the provision of alternative housing (even on an emergency basis). A court will be effectively blind to the possibility that its order will leave the occupier(s) homeless. In this regard, the PIE Act, as it currently stands, serves an important accountability function. It envisages that if a landowner is entitled to an eviction, but that eviction would leave the occupier homeless, a municipality will ordinarily be required to assist in the provision of alternative accommodation, or at least justify to a court why it cannot provide an alternative on the occupier's eviction" (see: http://web.wits.ac.za/NR/rdonlyres/7F93AE17-4914-49E0-B312

D2E608A41F7D/0/PIEACTAMENDMENTSSUBMISSIONCALS.pdf).
\end{abstract}

The Legal Resources Centre expressed surprise at government's statement that the PIE Act was never intended to protect mortgage bond and rent defaulters, given the remarks of Harms JA in Ndlovu, namely that " $(t) h e r e$ seems to be no reason in the general social and historical context of this country why the Legislature would not have wished not to afford this vulnerable group the protection of PIE": see http://www.lrc.org.za/ Docs/House/Steve's_PIE_Representations_Feb_2007.doc. Commenting on the proposed amendment of section 2 of the Act the Centre had the following to say (par 15):

"It allows the landlord on the court papers to simply state that PIE does not apply and to issue a summons as was done under ordinary old preconstitutional and pre-PIE laws and procedures. Accordingly the occupants will receive a summons in which the landowner simply claims ownership and seeks eviction. None of the protections and warnings (contemplated in the PIE Act) will appear on the face of the documents and no second notice of an impending application for eviction will be received. The municipal authorities will not be alerted that there is an impending eviction which could cause social disruption - and the defendant will only receive the papers once (not twice as PIE requires). Finally the expressly stated reminder of their right to legal assistance will be absent. Faced with this simple summons the presiding officer in the court is also not alerted to these issues and accordingly there would be no legal basis on the papers in undefended matters for the presiding officer to question or delay the requested eviction order. Unless the defendant occupants have been able to rush to court with assistance and insist that PIE does/should apply, eviction orders will quickly follow. If the occupants do get to court and satisfy the presiding officer that PIE may apply then the presiding officer will have no option but to dismiss the application already launched for eviction and the unfortunate owner will have to start all over again under PIE. The issue will get all the more complicated if some of the occupants get to the court and others don't - what is the presiding officer then obliged to do - evict 
those who haven't come under common law and tell the landowner that in respect of those who did, to recommence in terms of the amended PIE. However we submit that in the vast majority of cases this unusual and unnecessary dismissal of an ordinary application for eviction will not occur because the defendant occupants will not have come to court to effectively beg that PIE should apply - and they in all likelihood will be evicted by default, or after an application for summary judgment by the presiding magistrate. Thus this proposed manner of nullifying the Ndlovu decision creates a giant hole for landlords to avoid the intended purpose of PIE to ensure that there be eviction of unlawful occupiers from land in a fair manner."

It is submitted that the remarks made by both the Centre for Applied Legal Studies and the Legal Resources Centre need to be taken seriously. As stated earlier in this Note, not every landlord is a slumlord and not every tenant is a vulnerable victim of misguided land tenure policies of the past. There is no reason why commercially astute tenants of residential properties should enjoy the protection of the PIE Act, or putting it differently, why landlords should be prohibited from applying the common law to evict them. At the same time, however, it cannot be denied that there exists in South Africa a large group of tenants of residential properties that do require the protection of the PIE Act simply because the common law provides them with inadequate protection against unfounded and surprised evictions on the part of unscrupulous landlords. The get-up of the rental market in South Africa, and the different categories of landlords and tenants, must be properly understood.

A research project undertaken in 2006 by Shisaka Development Management Services (Pty) Ltd in association with the CSIR Built Environment (http://ftp.shf.org.za/sl_report1.pdf) revealed that the rental sector in 2001 comprised $29 \%$ of the overall housing sector (3,3 million households). It also pointed out that the rental sector comprises two subsectors, namely:

(a) The formal sub-sector which includes households renting a formal house or brick structure on a separate stand or yard, a flat in a block of flats, or a townhouse, cluster, or semi-detached house. This sub-sector comprised 2,7 million households in 2001 , making up $82 \%$ of the rental sector and $24 \%$ of the overall housing sector.

(b) The households sub-sector which includes households renting a formal house, flat or room in a backyard or an informal dwelling or shack in a back yard. This sub-sector comprised 0,6 million households in 2001, making up $18 \%$ of the rental sector and $5 \%$ of the overall housing sector.

According to the report, small scale landlords (those owning one or two rental properties or rooms) are managing all of the stock comprising the household sub-sector, but only a portion of the stock comprising the formal sub-sector. The study also shows (http://ftp.shf.org.za/sl_report1.pdf 7) that "(I)andlords are a diverse group made up of different categories that are motivated to operate in the rental sector by fundamentally different factors, financing and regulatory needs". They can be defined in various ways, such as size of operation, basis of residency status (ie, in-house or absent landlords), routes by which they became landlords (such as inheritance or 
purchase) or economic success. In terms of the latter category landlords are defined on the basis of their economic success or motivation, for example:

- Subsistence landlords are defined as those whose rooms are rented to sustain or augment the household's income, either for investment in completing or maintaining the dwelling or for everyday subsistence needs.

- Petty bourgeois landlords are defined as those that use the income from renting to invest in improvements to their quality of life, for example by carrying out house improvements or the purchase of consumer durables.

- Petty capitalist landlords are defined as those who own more than one property and produce dwellings for rent in order to expand and reproduce capital in the form of landed property.

The report refers to a study undertaken by Gardner Nurcha Research and Development: Informal Rental Development Programme (2005), in which eight categories of landlords were identified in terms of scale and type of rental stock they provide:

\begin{tabular}{|c|c|c|c|c|}
\hline Category & Sub-Sector & Form & $\begin{array}{l}\text { Type of } \\
\text { Accommodation } \\
\text { provided }\end{array}$ & Scale \\
\hline $\begin{array}{l}\text { Large } \\
\text { corporate } \\
\text { landlords }\end{array}$ & Formal rental & $\begin{array}{l}\text { Multiple owner listed } \\
\text { or unlisted registered } \\
\text { legal entity }\end{array}$ & $\begin{array}{l}\text { Multi-unit } \\
\text { accommodation } \\
\text { complexes }\end{array}$ & $\begin{array}{l}\text { Over } 100 \\
\text { units }\end{array}$ \\
\hline $\begin{array}{l}\text { Small } \\
\text { private } \\
\text { landlords }\end{array}$ & $\begin{array}{l}\text { Formal rental } \\
\text { sub-sector }\end{array}$ & $\begin{array}{l}\text { Single owner or } \\
\text { shareholder entity }\end{array}$ & $\begin{array}{l}\text { Multi-unit } \\
\text { accommodation } \\
\text { complexes }\end{array}$ & $\begin{array}{l}\text { Below } 100 \\
\text { units }\end{array}$ \\
\hline $\begin{array}{l}\text { Individual } \\
\text { landlords }\end{array}$ & $\begin{array}{l}\text { Formal rental } \\
\text { sub-sector }\end{array}$ & Private individuals & $\begin{array}{l}\text { Separate } \\
\text { accommodation } \\
\text { units }\end{array}$ & $\begin{array}{l}\text { Up to } 10 \\
\text { units }\end{array}$ \\
\hline $\begin{array}{l}\text { Social } \\
\text { Housing } \\
\text { Institutions }\end{array}$ & $\begin{array}{l}\text { Formal rental } \\
\text { sub-sector }\end{array}$ & $\begin{array}{l}\text { Take various legal } \\
\text { forms. Most are } \\
\text { registered as Social } \\
\text { Housing Institution } \\
\text { with the Social } \\
\text { Housing Foundation }\end{array}$ & $\begin{array}{l}\text { Multi-unit } \\
\text { accommodation } \\
\text { complexes }\end{array}$ & $\begin{array}{l}\text { Over } 100 \\
\text { units - } \\
\text { viability } \\
\text { between } \\
1500 \text { to } \\
2000 \text { units }\end{array}$ \\
\hline $\begin{array}{l}\text { Pubic rental } \\
\text { institutions }\end{array}$ & $\begin{array}{l}\text { Formal rental } \\
\text { sub-market }\end{array}$ & $\begin{array}{l}\text { Public agencies } \\
\text { (National, provincial } \\
\text { or local government } \\
\text { (or publicly owner } \\
\text { Special Purpose } \\
\text { Vehicle)) }\end{array}$ & $\begin{array}{l}\text { Multi-unit } \\
\text { accommodation } \\
\text { complexes }\end{array}$ & $\begin{array}{l}\text { Over } 100 \\
\text { units }\end{array}$ \\
\hline $\begin{array}{l}\text { Company } \\
\text { landlords }\end{array}$ & $\begin{array}{l}\text { Formal rental } \\
\text { sub-market }\end{array}$ & $\begin{array}{l}\text { Corporate entities not } \\
\text { directly engaged in } \\
\text { the housing sector }\end{array}$ & $\begin{array}{l}\text { Company owned } \\
\text { houses or } \\
\text { apartments }\end{array}$ & $\begin{array}{l}\text { Varies on } \\
\text { size of staff }\end{array}$ \\
\hline $\begin{array}{l}\text { Household } \\
\text { landlords }\end{array}$ & $\begin{array}{l}\text { Informal rental } \\
\text { sub-market }\end{array}$ & $\begin{array}{l}\text { Individual owners or } \\
\text { individuals who offer } \\
\text { rental opportunities on } \\
\text { land or buildings on } \\
\text { the property on which } \\
\text { they live }\end{array}$ & $\begin{array}{l}\text { Home room rental, } \\
\text { backyard dwellings } \\
\text { or site rental }\end{array}$ & $\begin{array}{l}1 \text { to } 20 \\
\text { units }\end{array}$ \\
\hline $\begin{array}{l}\text { Other } \\
\text { landlords }\end{array}$ & $\begin{array}{l}\text { Formal rental } \\
\text { sub-market }\end{array}$ & $\begin{array}{l}\text { Various } \\
\text { miscellaneous types } \\
\text { of rental }\end{array}$ & $\begin{array}{l}\text { Temporary } \\
\text { accommodation }\end{array}$ & Varies \\
\hline
\end{tabular}


It is not known whether government at any stage took into account data of this nature in its deliberations concerning the amendment of the PIE Act. It is submitted that it provides the type of information required in order to establish what categories of landlords should be subjected to the provisions of the PIE Act. Clearly a "one size fits all" approach is not the desired solution. In terms of the Ndlovu judgment all landlords renting out dwellings to natural persons have to comply with PIE; according to the Amendment Bill none has to (leaving aside sham leases). Neither approach is satisfactory from a commercial perspective. What would have to be identified are the categories of tenants requiring the protection of the PIE Act, or putting it differently, the categories of landlords to be exempted from the Act. This may well be a difficult task and pose some challenges from a legislative drafting point of view, but it is certainly not impossible. At least there would then be some scientific justifiable grounds for the inclusion or exemption of certain categories of landlords from the operation of the Act.

\section{Position should the Amendment Bill become law}

Should the amendments to the PIE Act proposed by the 2008 Amendment Bill become law, the effect would be that the eviction of tenants will be governed by the law as it stood prior to the judgment in Ndlovu. The only exception would be if a court is satisfied that any act or omission by the owner or person in charge of land was calculated to avoid the application of the Act, such as where a lease is found to be a sham transaction entered into merely to bypass the PIE Act. In the latter event the PIE Act will apply. It is submitted that the question whether the lease relied upon by the applicant is a sham can and should be raised by the Court mero motu, especially in cases where the tenant against whom the eviction is sought has not entered any appearance. This will to some degree be a safeguard to prevent sham landlords from bypassing the PIE Act. Such situations would rarely arise in the formal letting market.

The amendment of the PIE Act in the manner suggested by the 2008 Amendment Bill does not in any way affect section 26(3) of the Constitution, which provides that "no one may be evicted from their home ... without an order of Court made after considering all the relevant circumstances". The eviction of tenants will therefore still be subject to the constitutional protection afforded by section 26(3). The section requires closer examination:

- Section 26(3) in effect places a duty on a Court hearing an application or action for the eviction of a person from his or her home, not to issue the order until it has had an opportunity to consider all the relevant circumstances. Therefore an eviction order may not be issued, for example, by a clerk of the magistrate's court or the Registrar of the High Court in an application for default judgment: only the presiding judicial officer can issue such an order and then only after considering all the relevant circumstances: Cape Killarney Property Investments (Pty) Ltd Mahamba (2000 2 SA 67 (C)). 
- Section 26(3) has not changed the common law to the extent that an owner of residential property seeking an ejectment order based on common law, is now required to allege and prove relevant circumstances which would entitle the Court to issue the order: Ellis v Viljoen (2001 4 SA 795 (C)); Betta Eiendomme (Pty) Ltd v Ekple-Epoh (2000 4 SA 468 (W)); and Brisley $v$ Drotsky (2002 4 SA 1 (SCA)). The contrary view expressed in Ross v South Peninsula Municipality (2000 1 SA 589 (C)) is wrong. Accordingly, section 26(3) does not require a plaintiff to allege and prove circumstances irrelevant to its claim, such as that the respondents are not labour tenants: Woerman and Schutte NNO v Masondo (2002 1 SA 811 (SCA)).

- Section 26(3) does not require of a Court to be satisfied that the eviction is just and equitable. The Court is merely required to consider all relevant circumstances. Circumstances are only relevant for the purposes of section 26(3) if they are legally relevant: Brisley $v$ Drotsky (supra). The personal circumstances of the lessee should the eviction order be granted, are not relevant circumstances in the application of the section (Brisley $v$ Drotsky supra). Except in cases where specific legislation applies, it is right and proper that an owner should be granted an ejectment order against a defendant who has no business interfering with the owner's possession of his property. If those are the only "relevant circumstances" placed before the Court, the owner must be entitled to an eviction order. If there are other "relevant circumstances" upon which the defendant wishes to rely in justifying his continued occupation, the onus rests on him to allege and prove them, whatever they may be. This approach is not inconsistent with anything in the Constitution; it is in line with the provisions of section 25(1) of the Constitution which stipulate that no one may be deprived of property except in terms of law of general application, and that no law may permit arbitrary deprivation of property (Brisley v Drotsky supra).

It is submitted that in view of this interpretation of section 26(3) by the Courts, the practical effect is that the eviction of tenants holding over is for all intents and purposes governed by common law. An owner-landlord is required to establish no more than his title to the premises and that the tenant is in possession but has no right to be. The tenant can oppose the eviction on legal grounds only, for example a ius retentionis. Equitable considerations do not enter the picture, neither does compassion. The only pertinent requirement introduced by section 26(3) is that an eviction order cannot be granted by a clerk of the magistrate's court or the Registrar of the High Court in an application for default judgment: only a presiding judicial officer can do so.

It is respectfully submitted that it remains to be seen whether the Constitutional Court will follow the same approach when it comes to the application of section 26(3) in relation to the eviction of tenants holding over. More particularly, the question is whether the Constitutional Court will endorse the view expressed by the Supreme Court of Appeal in Brisley $v$ Drotsky (supra), namely that circumstances are relevant for the purposes of 
section 26(3) only if they are legally relevant. It may be rightfully asked whether the rights and needs of the elderly, children, disabled persons and households headed by women are not also relevant considerations, as would be the constitutional value of human dignity and the position of those that will be rendered homeless following the eviction. Should this approach be adopted it would for all intents and purposes mean that the substantive requirements for an eviction as laid down in the PIE Act will still apply in respect of the eviction of tenants, despite the amendment of section 2 of the Act by the 2008 Amendment Bill. All that will not apply would be the procedural requirements of the Act.

\section{Conclusion}

The eviction of tenants after termination of a lease is a controversial issue. Common law clearly favours the landlord. Following the Supreme Court of Appeal's judgment in Ndlovu, the PIE Act now governs the eviction of tenants after termination of a lease. However, the PIE Act aims at balancing the competing interests of landlords and tenants in the eviction process but does so without having regard to the different categories of landlords and tenants in the residential rental market. The result is that the Act affords protection to tenants who are not in need of protection over and above what the common law offers. The PIE Amendment Bill 2008 seeks to undo the Ndlovu judgment - except in cases where the lease is a sham - but again there is no distinction drawn between the various categories of landlords and tenants. The outcome is that tenants in need of the safeguards introduced by PIE, would now not enjoy any protection under the Act. Section 26(3) of the Constitution, which prohibits the eviction from a home without a court order made after considering all relevant circumstances, has been interpreted by the Supreme Court of Appeal in a manner strongly favouring a landlord, effectively entrenching the common law. Should the PIE Amendment Bill be enacted in its current form, common law will for all intents and purposes govern the eviction of all tenants. While landlords may find this a pleasing development, it is questionable whether this is sustainable in the long run. The ideal position would be to simply exclude from the operation of the PIE Act, those landlord-tenant relationships that need to be protected by the PIE Act. Identifying those relationships, and drafting the legislative provisions, may well be a challenging task but not an impossibility. 